4 Fell HB, Mellanby E. Effects of hypervitaminosis A on foetal mouse bone cultivated in vitro. $\mathrm{Br} M e d \mathcal{F} 1950 ; \mathrm{ii}: 535-9$.

${ }^{5}$ Raisz LG. Bone resorption in tissue culture. Factors influencing the response to parathyroid hormone. $\mathcal{F}$ Clin Invest 1965;44(1):103-16.

6 Wolbach SB. Vitamin A deficiency and excess in relation to skeletal growth. F Bone foint Surg 1947;29:171-92.

${ }^{7}$ Barnicot NA, Datta SP. Vitamin A and bone. In: Bourne GH, ed. The biochemistry and physiology of bone. New York and London: Academic Press, 1972:197-229.

8 Wieland RG, Henricks FH, Amat y Leon F, Guttierez L, Jones JC. Hypervitaminosis A with hypercalcaemia. Lancet $1971 ; \mathrm{i}: 698$.

${ }^{9} \mathrm{Katz}$ CM, Tzagournis M. Chronic adult hypervitaminosis A with hypercalcaemia. Metabolism 1972;21(12):1172-6.

10 Frame B, Jackson CE, Reynolds WA, Umphrey JE. Hypercalcaemia and skeletal effects in chronic hypervitaminosis A. Ann Intern Med 1974; $\mathbf{8 0}: 44-8$.

${ }^{11}$ Meinhard EA, Wadbrook DG, Ring C, et al. Computer card morphometry in uraemic bone disease. In: Norman AW, et al, eds. Vitamin $D$ and problems related to uraemic bone disease; proceedings of 2 nd workshop on vitamin D. Berlin: Walter de Gruyter, 1975:547-52.

12 Varghese Z, Moorhead JF, Tatler GLV, Baillod RA, Wills MR, Moorhead JF. Plasma hydroxyproline in renal osteodystrophy. Proc Eur Dial Transplant Assoc 1973;10:187-96.

${ }^{13}$ Farrington K, Varghese Z, Moorhead JF. Human calcitonin in the treatment of renal osteodystrophy. $\mathcal{F}$ Lab Clin Med 1980;96:299-306.

14 Neeld JB, Pearson WN. Macro- and micromethods for the determination of serum vitamin A using Trifluoroacetic acid. 7 Nutr 1963;79:454-62.
15 Kleiner-Bössaler A, Deluca HF. Formation of retinoic acid from retinol in the kidney. Arch Biochem Biophys 1971;142:371-7.

16 Werb R, Clark WF, Lindsay RM, Jones EOP, Linton AL. Serum vitamin A levels and associated abnormlities in patients on regular dialysis treatment. Clin Nephrol 1979;12(2):63-8.

17 Liu SH, Chu HI. Studies of calcium and phosphorus metabolism with special reference to the pathogenesis and effect of dihydrotachysterol (DHT) and iron. Medicine (Baltimore) 1943;22:103-61.

${ }^{18}$ Stanbury SW, Lumb GA. Metabolic studies in renal osteodystrophy. I Calcium, phosphorus and nitrogen metabolism in rickets, osteomalacia and hyperparathyroidism complicating chronic uraemia and in the osteomalacia of the adult Fanconi syndrome. Medicine (Baltimore) $1962 ; 41: 1-31$.

19 Irving JT. Vitamin A and dental disease. F Physiol (Lond) 1949;108:92-101. Dingle JT. Studies on the mode of action of excess vitamin A 3. Biochem $\mathcal{y}$ 1961;79:509-12.

${ }^{21}$ Basset BE, Packer L. Response of isolated lysosomes to vitamin A. 7 Cell Biol $1965 ; 27: 448-50$.

2 Caffey J. Chronic poisoning due to excess of vitamin A. American fournal of Roentgenology (Springfield, Ill) $1951 ; 65: 12-26$.

23 Jowsey J, Riggs BL. Bone changes in a patient with hypervitaminosis A 7 Clin Endocrinol Metab 1968;28:1833-5. A stimulation of parathyroid hormone: interactions with calcium, hydrocortisone, and vitamin $\mathrm{E}$ in bovine parathyroid tissues and effects of vitamin A in man. Eur $\mathcal{F}$ Clin Invest 1977;7:307-14.

(Accepted 14 May 1981)

\title{
A protein in urine associated with muscle disease and muscle damage
}

\author{
NEIL FREARSON， ROGER D TAYLOR，S VICTOR PERRY
}

\begin{abstract}
Analysis of the protein composition of human urine by high-resolution two-dimensional electrophoresis showed that several features are associated with neuromuscular diseases, the best defined being the appearance in the urine of a small amount of a protein that migrates on the electropherogram as a characteristic spot (spot $\mathrm{C}$ ). This spot consists of a protein of apparent molecular weight 26000 and isoelectric point $5 \cdot 3$. The spot was usually present in the urine of patients suffering from diseases in which the musculature was directly affected but was rarely found in other patients and normal subjects.

The protein responsible for spot $C$ appears to be an index of muscle damage caused by a number of conditions. Attempts are being made to isolate enough of the protein to permit its identification.
\end{abstract}

\section{Introduction}

The analysis of the protein composition of human urine by high-resolution two-dimensional electrophoresis provides a highly sensitive index of the functional state of an individual. ${ }^{12}$ By applying this technique to patients with neuromuscular diseases we have observed several features in the urinary protein pattern that are associated with these diseases. ${ }^{1}$ The best defined

\footnotetext{
Department of Biochemistry, University of Birmingham, PO Box 363, Birmingham B15 2TT

NEIL FREARSON, BSC, PHD, research fellow ROGER D TAYLOR, BSC, research associate $S$ VICTOR PERRY, SCD, FRS, professor
}

and most consistent feature is the appearance in the urine of a small amount of a protein that migrates on the electropherogram as a characteristic spot; we have designated this spot $\mathrm{C}$.

\section{The protein and its prevalence}

From its electrophoretic behaviour spot $\mathrm{C}$ consists of a protein of apparent molecular weight 26000 and isoelectric point 5.3.

We studied the prevalence of spot $\mathrm{C}$ in electropherograms of urine from 107 normal subjects and 130 patients with various neuromuscular diseases. Spot $\mathrm{C}$ was most pronounced and was invariably observed on electropherograms of the urine of boys with Duchenne muscular dystrophy, who were estimated to excrete about $100 \mu \mathrm{g}$ a day (table). It was also usually present in the urine of patients suffering from limbgirdle dystrophy, spinal muscular atrophies, and dystrophia myotonica. Spot $\mathrm{C}$ was not observed in the urine of patients partially immobilised by other disabilities such as spina bifida, cerebral palsy, and congenital deformity, in which the musculature is not directly affected. In preliminary studies we did not detect the protein responsible for spot $C$ in the urine of patients with myasthenia gravis and multiple sclerosis.

\section{Discussion}

We believe that the presence of the protein responsible for spot $\mathrm{C}$ in urine is an index of muscle damage produced by a number of conditions and not the direct product of a modified gene associated with a particular neuromuscular disease. The protein is probably present in normal muscle, although the evidence for this is so far circumstantial for we have not been able to show its presence by electrophoresis of extracts of this tissue and have not detected it in the serum of normal people or patients with Duchenne muscular dystrophy. It was detected in the urine of normal men for a day or two after a bout of vigorous exercise. It was also observed in the urine of patients with a history of circu- 
latory insufficiency-for example, after myocardial infarction or in cases of arterial insufficiency of a leg.

Spot $\mathrm{C}$ was detected in about $60 \%$ of the urine samples from carriers of Duchenne muscular dystrophy. Only rarely $(4 \%$ of cases) were traces of it seen in the electropherograms of urine from normal subjects (table). In these cases the presence of the protein in the urine may possibly have been due to mild muscle damage from exercise, sprains, or falls, etc.

The protein responsible for spot $\mathrm{C}$ does not appear to be identical with any of the muscle enzymes known to be present in

Prevalence of spot $C$ in electropherograms of urine from normal subjects and patients with neuromuscular diseases

\begin{tabular}{|c|c|c|c|c|}
\hline & \multicolumn{2}{|c|}{ Age (years) } & \multirow{2}{*}{$\begin{array}{l}\text { Total No } \\
\text { studied }\end{array}$} & \multirow{2}{*}{$\begin{array}{l}\text { No with } \\
\text { spot C }\end{array}$} \\
\hline & Range & Mean & & \\
\hline & \multicolumn{2}{|c|}{ Normal subjects } & & \\
\hline Adult women & $18-55$ & $27 \cdot 5$ & 34 & 2 \\
\hline Pregnant women & $18-33$ & & 24 & 0 \\
\hline Adult men & $20-35$ & $28 \cdot 2$ & 25 & $\begin{array}{l}0 \\
2\end{array}$ \\
\hline \multirow[t]{2}{*}{ Boys } & $6-18$ & $10 \cdot 0$ & 26 & 2 \\
\hline & \multicolumn{2}{|c|}{ Disabled people } & & \\
\hline \multirow[t]{2}{*}{ Male patients } & $6-39$ & $18 \cdot 6$ & 14 & 1 \\
\hline & \multicolumn{2}{|c|}{$\begin{array}{c}\text { Patients with } \\
\text { Duchenne muscular } \\
\text { dystrophy }\end{array}$} & & \\
\hline Boys & $6-22$ & $17 \cdot 2$ & 31 & 31 \\
\hline $\begin{array}{l}\text { Mothers: } \\
\text { Obligatory carriers }\end{array}$ & $39-57$ & & 21 & 12 \\
\hline Isolated cases & $23-45$ & $36 \cdot 0$ & 11 & 3 \\
\hline \multirow[t]{2}{*}{ Sisters } & $11-25$ & $17 \cdot 1$ & 10 & 5 \\
\hline & \multicolumn{2}{|c|}{$\begin{array}{l}\text { Patients with other } \\
\text { neuromuscular diseases }\end{array}$} & & \\
\hline \multirow{6}{*}{$\begin{array}{l}\text { Limb-girdlc muscular dystrophy } \\
\text { Werdnig Hoffman paralysis } \\
\text { Spinal muscular atrophy } \\
\text { Peroneal muscular atrophy* } \\
\text { Dystrophia myotonica } \\
\text { Myasthenia gravis } \\
\text { Multiple sclerosis }\end{array}$} & & & 2 & 2 \\
\hline & $14-21$ & 18 & 3 & 2 \\
\hline & $11-19$ & & 2 & 2 \\
\hline & $15-62$ & 39.0 & 12 & $\begin{array}{c}3-4 \\
9\end{array}$ \\
\hline & $16-61$ & 43.8 & 10 & 0 \\
\hline & $29-64$ & $46 \cdot 7$ & 9 & 0 \\
\hline
\end{tabular}

*Including Charcot-Marie-Tooth atrophy. the serum of patients with muscular dystrophy. In this respect it is interesting that no spot corresponding to creatine kinase could be detected on electropherograms of the urine of these patients, even though spot $\mathrm{C}$ was clearly identifiable. On the other hand, unlike spot $\mathrm{C}$, creatine kinase was clearly visible as a protein-staining spot on electropherograms of serum from these patients.

Our studies thus indicate that the presence in the urine of protein migrating as spot $\mathrm{C}$ is characteristic of diseases in which the muscle is clearly affected. The detection of this protein in urine, particularly when methods for its radioimmune assay have been developed, might be a useful sensitive aid in confirming the diagnosis of muscle disease and under certain conditions in assessing muscle damage. It might also have a role in the detection of the carrier state in Duchenne muscular dystrophy. We are now attempting to isolate the protein from the urine of boys with Duchenne muscular dystrophy in sufficient amounts to permit its identification.

We are grateful to friends, colleagues, and headmasters of special schools in the Birmingham area for their co-operation in collecting urine samples and particularly wish to thank Drs Sarah Bundey, D Gardner-Medwin, and P S Harper for providing samples and the diagnoses. This work was supported by a grant from the Birmingham NEC Lions Club administered through the Muscular Dystrophy Group of Great Britain.

\section{References}

${ }^{1}$ Frearson N, Taylor RD, Perry SV. Proteins in the urine associated with Duchenne muscular dystrophy and other neuromuscular diseases. Clin $S_{c i}$ (in press).

2 Anderson NG, Anderson NL, Tollaksen GL. Proteins of human urine. I. Concentration and analysis by two-dimensional electrophoresis. Clin Chem 1979;25:1199-210.

(Accepted 15 May 1981)

\title{
$\underline{\underline{m}}$

\section{Haemolytic anaemia after cisplatin treatment}

\author{
J A LEVI, R S ARONEY, D N DALLEY
}

\begin{abstract}
Normochromic or normocytic anaemia is a common side effect of treatment with cisplatin. Two patients treated with cisplatin $100 \mathrm{mg} / \mathrm{m}^{2}$ in combination with vinblastine, bleomycin, and actinomycin $D$ developed haemolytic anaemia. Neither patient had evidence of haemolysis before treatment, and in both cases severe haemolytic anaemia developed after several courses of cisplatin and when the cancer had regressed almost completely.

The importance of haemolysis in the development of anaemia after cisplatin treatment has not been investigated fully and further studies are needed.
\end{abstract}

\footnotetext{
Department of Oncology, Royal North Shore Hospital of Sydney, St Leonards, New South Wales 2065, Australia

J A LEVI, FRACP, physician

R S ARONEY, $M B$, BS, fellow

D N DALLEY, MB, BS, registrar
}

\section{Introduction}

cis-Dichlorodiammineplatinum (II) (cisplatin) is a cancer chemotherapeutic agent of value in several types of tumour. ${ }^{1}$ Major side effects reported with cisplatin include gastrointestinal and renal toxicities, and ototoxicity ${ }^{2}$; anaemia has been reported in $9-40 \%$ of patients treated with cisplatin. ${ }^{2}$ The anaemia is usually normochromic and normocytic in type and considered to be secondary to depression of erythropoiesis, though adequate studies to clarify the mechanisms responsible have not been reported. We report two cases of haemolytic anaemia occurring after cisplatin treatment.

\section{Case reports}

Case 1-A 37-year-old man with metastatic mixed embryonal cell carcinoma and teratocarcinoma of the testis affecting lungs and retroperitoneal lymph nodes started chemotherapy with cisplatin $100 \mathrm{mg} / \mathrm{m}^{2}$ every three weeks in combination with vinblastine, bleomycin, and actinomycin D on 7 September 1978. His initial haemoglobin concentration was $16.3 \mathrm{~g} / \mathrm{dl}$. There was virtually complete regression of all metastatic disease over the next nine weeks. After the third course of cisplatin (total dose $503 \mathrm{mg}$ ) his haemoglobin 